\title{
Communication
}

[Comunicação]

\section{Adiponectin serum levels in female dogs bearing mammary gland carcinomas}

[Níveis séricos de adiponectina em cadelas portadoras de carcinomas mamários]

\author{
I.B.R. Souza ${ }^{1}$, C.V. Cardoso ${ }^{2}$, A.A.F. Pereira ${ }^{1}$, S.C. Poppe ${ }^{, 1,2}$, E.F. Bondan ${ }^{1,2^{*}}$ \\ ${ }^{1}$ Escola de Medicina Veterinária - Universidade Cruzeiro do Sul - São Paulo, SP \\ ${ }^{2}$ Programa de pós-graduação - Universidade Paulista - São Paulo, SP
}

Adipose tissue is currently recognized as a complex organ with endocrine, metabolic and immune regulatory roles, releasing over 20 hormones and signaling molecules termed adipokines or adipocytokines, that act locally in an autocrine and paracrine way but also peripherally in an endocrine fashion (Booth et al., 2015; Katira and Tan, 2016). Amongst these bioactive molecules, adiponectin (APN) is the only adipokine with an inverse relationship with fat mass and therefore is abundant in lean individuals (German et al., 2010; Ricci and Bevilacqua, 2012). Adiponectin has been proposed as having key roles in the pathogenesis of obesity-associated cancers along with other diseases such as type 2 diabetes (Dalamaga et al., 2012). Under normal circumstances adiponectin presents anti-inflammatory, pro-apoptotic and anti-proliferative effects (Booth et al., 2015).

In humans, hypoadiponectinemia is associated to obesity and to increased risk for a wide variety of malignancies, including breast, endometrial, colorectal, gastric, esophageal, pancreatic, hepatic, prostatic, pulmonar and haematological cancers, as well as to renal cell carcinomas (Kelesidis et al., 2006; Dalamaga et al., 2012; Both et al., 2015; Lee et al., 2015; Katira and Tan, 2016). Thus, the implication of adiponectin in the pathogenesis of cancer is well established in humans, but still undetermined in dogs.

In view of the absence of reports regarding adiponectin levels in dogs and the occurrence of malignant neoplasms, the present study aimed to compare the serum levels of adiponectin in

Recebido em 23 de maio de 2018

Aceito em 4 de dezembro de 2018

*Autor para correspondência (corresponding author)

E-mail: ef.bondan@gmail.com clinically normal bitches and in those with a diagnosis of mammary carcinoma. The present investigation was approved by the Ethics Committee on Animal Use (CEUA) of the University Cruzeiro do Sul (São Paulo, SP, Brazil) under protocol number 031/2016 and the consent of the owners was obtained for all participating dogs.

Twenty-two female dogs of different breeds and ages ranging from 2 to 16 years were selected. Eleven of them were grouped in group I after receiving histopathologic diagnosis of simple tubular mammary carcinoma staged as Stage 4 [T - any tumor size; N1 (positive); M0] according to the $\mathrm{T}$ (tumor size), $\mathrm{N}$ (lymph node status) and $\mathrm{M}$ (metastasis) system (Sorenmo et al., 2013), and 11 healthy female dogs were included in group II. Clinically normal females had to be more than 2 years old without intestinal or blood parasites and have had a normal physical examination at least 3 months before blood collection. Ultrasonographic evaluation of lymph nodes and liver and radiological examination of the lungs for metastasis research of canine mammary tumor were performed. Three milliliters of blood were collected from the cephalic vein and fractioned into two parts. One milliliter was treated with the anticoagulant EDTA and used for complete blood cell count and determination of hemoparasites; the remainder was used to determine serum concentrations of adiponectin by adiponectin commercial Enzyme-Linked Immunosorbent Assay kit (Canine Adiponectin ELISA kit, catalog number EZCADP63K, Merck Millipore, Billerica, MA, USA), according to manufacturer's instructions. 
The normality of the data was assessed using Kolmogorov-Smirnov test and analysis was made using the unpaired t-test. Data were reported as means \pm standard deviation $(\mathrm{SD})$ and significance was set at $\mathrm{P}<0.05$. Demographic characteristics of both groups (carcinoma- bearing and clinically normal female dogs) are shown in Table 1. Individual data for breed, age, weight, body condition score (Laflamme, 1997) and serum adiponectin levels (in $\mu \mathrm{g} / \mathrm{mL}$ ) are shown in Table 2.

Table 1. Demographic characteristics of the female dogs bearing mammary gland carcinomas and those clinically normal

\begin{tabular}{ccc}
\hline Variables & $\begin{array}{c}\text { Carcinoma-bearing female dogs } \\
(\mathrm{n}=18)\end{array}$ & $\begin{array}{c}\text { Clinically normal female dogs }(\mathrm{n}= \\
18)\end{array}$ \\
\hline $\begin{array}{c}\text { Age, years; mean } \pm \text { SD (range) } \\
\text { Breed, number (\%) }\end{array}$ & $8.91 \pm 3.24(3-15)$ & $6.18 \pm 4.14(2-16)$ \\
Mixed & $6(54.55 \%)$ & $8(72.73 \%)$ \\
$\begin{array}{c}\text { Pure breed } \\
\text { Weight, kg; mean } \pm \text { SD } \\
\text { (range) }\end{array}$ & $5(45.45 \%)$ & $3(27.27 \%)$ \\
\hline
\end{tabular}

Age and weight analyzed by unpaired t-test; breed by Chi-square test.

Table 2. Breed, age, weight, body condition score (BCS) and serum adiponectin levels in $\mu \mathrm{g} / \mathrm{mL}$ for female dogs bearing mammary gland carcinomas and those clinically normal

\begin{tabular}{|c|c|c|c|c|c|c|c|c|c|}
\hline $\begin{array}{c}\text { Mammary } \\
\text { carcinoma } \\
- \\
\text { bearing } \\
\text { dogs }\end{array}$ & $\begin{array}{l}\text { Breed } \\
\text { and age }\end{array}$ & $\begin{array}{l}\text { Adiponecti } \\
\mathrm{n}(\mu \mathrm{g} / \mathrm{mL})\end{array}$ & Weight (kg) & $\begin{array}{c}\text { BC } \\
\text { S }\end{array}$ & $\begin{array}{c}\text { Clinicall } \\
\text { y normal } \\
\text { dogs }\end{array}$ & $\begin{array}{l}\text { Breed } \\
\text { and age }\end{array}$ & $\begin{array}{l}\text { Adiponecti } \\
\mathrm{n}(\mu \mathrm{g} / \mathrm{mL})\end{array}$ & $\begin{array}{l}\text { Weight } \\
(\mathrm{kg})\end{array}$ & $\begin{array}{c}\text { BC } \\
\text { S }\end{array}$ \\
\hline 1 & $\begin{array}{l}\text { Poodle, } \\
11 \mathrm{yrs}\end{array}$ & 1.84 & 4.85 & 4 & 1 & $\begin{array}{l}\text { Mixed, } \\
8 \text { yrs }\end{array}$ & 7.70 & 21.0 & 7 \\
\hline 2 & $\begin{array}{l}\text { Mixed, } \\
15 \text { yrs }\end{array}$ & 3.00 & 2.5 & 4 & 2 & $\begin{array}{l}\text { Mixed, } \\
7 \mathrm{yrs}\end{array}$ & 6.70 & 18.8 & 7 \\
\hline 3 & $\begin{array}{c}\text { Poodle, } \\
6 \mathrm{yrs}\end{array}$ & 3.85 & 5.75 & 5 & 3 & $\begin{array}{l}\text { Mixed, } \\
3 \text { yrs }\end{array}$ & 5.27 & 26.0 & 8 \\
\hline 4 & $\begin{array}{c}\text { Poodle, } \\
3 \mathrm{yrs}\end{array}$ & 4.40 & 12.8 & 8 & 4 & $\begin{array}{l}\text { Mixed, } \\
2 \mathrm{yrs}\end{array}$ & 6.46 & 12.3 & 6 \\
\hline 5 & $\begin{array}{c}\text { Mixed, } \\
11 \text { yrs }\end{array}$ & 4.15 & 9.0 & 7 & 5 & $\begin{array}{c}\text { Poodle, } \\
16 \text { yrs }\end{array}$ & 3.39 & 5.65 & 5 \\
\hline 6 & $\begin{array}{c}\text { Poodle, } \\
10 \text { yrs }\end{array}$ & 4.90 & 9.3 & 7 & 6 & $\begin{array}{l}\text { Mixed, } \\
5 \mathrm{yrs}\end{array}$ & 1.99 & 8.35 & 5 \\
\hline 7 & $\begin{array}{c}\text { Mixed, } \\
8 \text { yrs }\end{array}$ & 3.75 & 28.8 & 7 & 7 & $\begin{array}{l}\text { Mixed, } \\
10 \mathrm{yrs}\end{array}$ & 1.92 & 10.9 & 5 \\
\hline 8 & $\begin{array}{l}\text { Mixed, } \\
9 \text { yrs }\end{array}$ & 3.73 & 13.1 & 5 & 8 & $\begin{array}{c}\text { Yorkshire, } \\
7 \text { yrs }\end{array}$ & 6.67 & 3.95 & 5 \\
\hline 9 & $\begin{array}{l}\text { Mixed, } \\
6 \text { yrs }\end{array}$ & 2.12 & 18.0 & 5 & 9 & $\begin{array}{l}\text { Mixed, } \\
4 \text { yrs }\end{array}$ & 7.50 & 13.9 & 4 \\
\hline 10 & $\begin{array}{l}\text { Mixed, } \\
8 \text { yrs }\end{array}$ & 7.20 & 19.0 & 5 & 10 & $\begin{array}{l}\text { Mixed, } \\
4 \text { yrs }\end{array}$ & 6.57 & 16.7 & 7 \\
\hline 11 & $\begin{array}{l}\text { Poodle, } \\
11 \mathrm{yrs}\end{array}$ & 1.98 & 9.15 & 6 & 11 & $\begin{array}{c}\text { Chihuahua } \\
2 \text { yrs }\end{array}$ & 7.53 & 2.15 & 4 \\
\hline $\begin{array}{l}\text { Mean } \\
\pm \text { SD }\end{array}$ & $\begin{array}{c}8.91 \pm 3.2 \\
4 \mathrm{yrs}\end{array}$ & $\begin{array}{c}3.72^{\mathrm{a}} \pm \\
1.54 \\
\mu \mathrm{g} / \mathrm{mL}\end{array}$ & $\begin{array}{c}12.02 \pm 7.58 \mathrm{k} \\
\mathrm{g}\end{array}$ & & & $\begin{array}{c}6.18 \pm \\
4.14 \\
\text { yrs }\end{array}$ & $\begin{array}{c}5.61^{\mathrm{b}} \pm \\
2.18 \\
\mu \mathrm{gl} / \mathrm{mL}\end{array}$ & $\begin{array}{c}12.70 \pm 7.49 \mathrm{k} \\
\mathrm{g}\end{array}$ & \\
\hline
\end{tabular}

BCS - body condition score according to Laflamme (1997). Adiponectin levels, age and weight analyzed by unpaired t-test. Distinct letters represent significant different results $(\mathrm{P}<0.05)$. 
Results showed that female dogs diagnosed with mammary carcinomas in group I had significantly lower serum levels of adiponectin (mean of $3.72 \pm 1.54 \mu \mathrm{g} / \mathrm{mL}, \mathrm{P}<0.05$ ) compared to females considered healthy from group II (mean of $5.61 \pm 2.18 \mu \mathrm{g} / \mathrm{mL})$.

Obesity is a common nutritional problem in small animal medicine, being characterized by excessive adipose tissue accumulation in the body. Ideally, fat mass in dogs and cats must account for approximately 15 to $20 \%$ of total body weight. Thus, when body weight exceeds ideal body weight by 10 to $20 \%$ they tend to be considered overweight; when this excess is by 20 to $30 \%$ they are identified as obese (Park et al., 2014; Loftus and Wakshlag, 2015). According to the body condition score system for dogs (Laflamme, 1997), both groups in our study presented an equal proportion of lean (scores 4 and $5, \mathrm{n}=6$ ), overweight (scores 6 and $7, n=4$ ) and obese (scores 8 or $9, \mathrm{n}=1$ ) animals and average weight in carcinoma-bearing bitches and those clinically normal did not differ significantly (respectively, 12.02 and $12.70 \mathrm{~kg}$ ), indicating that the adiponectin differences found were not related to weight variation between both groups. It is described in dogs that the trend of adiponectin secretion does not appear to follow the human paradigm as adiposity does not appear to affect adiponectin secretion. Dogs may have robust adiponectin secretion regardless of obesity or overweight (Verkest et al., 2011; Loftus and Wakshlag, 2015), although a few studies identified that obese animals had lower adiponectin levels than lean dogs (Ishioka et al., 2006; Park et al., 2014). Some of these discrepancies may be due to the effects of other hormones on adiponectin secretion (such as thyroxine, which has negative effects on such secretion), to methodological problems or to other unrecognized factors (Loftus and Wakshlag, 2015). On the other hand, according to literature, influences such as breed, sex, age and neutering status do not appear to change canine adiponectin production (Verkest et al., 2011; Loftus and Wakshlag, 2015).

In dogs, differences in obesity prevalence among cancer types do not suggest a congruous effect of obesity on cancer expression or a differential effect of specific cancer types on weight status (Weeth et al., 2007). So, the association between obesity and cancer remains speculative in this species.

Additionally, no significant differences were found in our investigation between both groups relative to age and weight of the animals, as well as in the proportion of pure breeds in the carcinoma-bearing females group (5/11) compared to that in the clinically normal group (3/11). Despite the small number of animals in each group, it is important to note that the group of bitches diagnosed with mammary carcinomas was homogeneous regarding the morphological presentation of the tumor and its biological behavior since all tumors were in very similar stages.

It is suggested that there are two ways adiponectin can retard cancer progression - either directly on the tumor cells since several cancer lines express adiponectin receptors (AdipoR1 and AdipoR2), or through its insulin-sensitizing effects (Dalamaga et al., 2002). Decreased adiponectin receptor expression is associated with many human malignancies, contributing to cancer progression as the protective effects of adiponectin may be reduced (Katira and Tan, 2016). In humans, low adiponectin levels are clearly associated with stage of colorectal cancer, indicating that hypoadiponectinemia is connected to poor prognosis and carcinogenesis (Booth et al., 2015). In this context, the results found in our investigation tend to corroborate the human studies that associate lower adiponectin levels and the development of malignant tumors.

Keywords: dogs, adiponectin, cancer, mammary gland, obesity

\section{RESUMO}

Em seres humanos, a adiponectinemia está associada à obesidade e ao risco aumentado a uma ampla variedade de cânceres. Embora o papel dessa adipocina esteja bem documentado na patogênese do câncer em humanos, tal associação permanece a ser determinada em cães. Nesses animais, a relação da adiponectina com a carcinogênese parece ser ainda meramente especulativa. Nesse contexto, buscou-se nesta investigação comparar os níveis séricos de adiponectina em fêmeas hígidas e em portadoras de 
carcinomas mamários com diagnóstico histopatológico de carcinoma mamário tubular simples estágio 4, com comprometimento de linfonodos, porém sem metástases a distância detectadas. Foi observado que as cadelas diagnosticadas com carcinoma mamário tiveram níveis séricos de adiponectina significativamente menores (média de 3,72 $\pm 1,54 \mu \mathrm{g} / \mathrm{mL}, P<0,05$ ) em relação às fêmeas consideradas

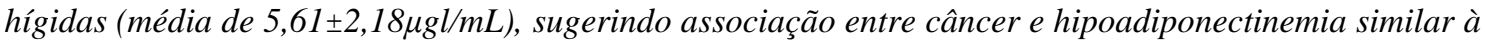
encontrada em humanos. Em relação à idade e ao peso corporal dos animais do estudo, não foi encontrada diferença significativa entre os grupos. Os resultados encontrados nas cadelas portadoras de carcinoma mamário do presente estudo corroboram a associação já descrita em humanos entre ocorrência de carcinogênese e baixos níveis de adiponectina.

Palavras-chave: cães, adiponectina, câncer, mama, obesidade

\section{ACKNOWLEDGEMENTS}

The authors are grateful to all dog owners who participated in this study.

\section{REFERENCES}

BOOTH, A.; MAGNUSON, A.; FOUTS, J.; FOSTER, M. Adipose tissue, obesity and adipokines: role in cancer promotion. Horm. Mol. Biol. Clin. Investig., v.21, p.57-74, 2015.

DALAMAGA， M.; DIAKOPOULOS， K.N.; MANTZOROS, C.S. The role of adiponectin in cancer: a review of current evidence. Endocr. Rev., v.33, p.547-594, 2012.

GERMAN, A.J.; RYAN, V.H.; VERMAN, A.C. et al. Obesity, its associated disorders and the role of inflammatory adipokines in companion animals. Vet. J., v.185, p.4-9, 2010.

ISHIOKA, K.; OMACHI, A.; SHIBATA, H.; et al. Canine adiponectin: cDNA structure, mRNA expression in adipose tissues and reduced plasma levels in obesity. Res. Vet. Sci., v.80, p.127-132, 2006.

KATIRA, A.; TAN, P.H. Evolving role of adiponectin in cancer controversies and update. Cancer Biol. Med., v.13, p.101-119, 2016.

KELESIDIS, I.; KELESIDIS, T.; MANTZOROS, C.S. Adiponectin and cancer: a systematic review. Br. J. Cancer, v.94, p.12211225, 2006.

LAFLAMME, D.P. Development and validation of a body condition score system for dogs. Canine Pract., v.22, p.10-15, 1997.
LEE, C.H.; WOO, Y.C.; WANG, Y. et al. Obesity, adipokines and cancer: an update. Clin. Endocrinol., v.83, p.147-156, 2015.

LOFTUS, J.P.; WAKSHLAG, J.J. Canine and feline obesity: a review of pathophysiology, epidemiology, and clinical management. Vet. Med. Res. Rep., v.6, p.49-60, 2015.

PARK, H.J.; LEE, S.E.; SEO, K.W. et al. Leptin, adiponectin and serotonin levels in lean and obese dogs. BMC Vet. Res., v.10, p.113-120, 2014.

RICCI, R.; BEVILACQUA, F. The potential role of leptin and adiponectin in obesity: a comparative review. Vet. J., v.191, p.292-298, 2012.

SORENMO, K.U.; WORLEY, D.R.; GOLDSCHMIDT, M.H. Tumors of the mammary gland. In: WITHROW, S.J. et al. Withrow \& MacEwen's small animal clinical oncology. 5.ed. St. Louis: Elsevier, 2013. p.538556.

VERKEST, K.R.; ROSE, F.J.; FLEEMAN, L.M. et al. Adiposity and adiponectin in dogs: investigation of causes of discrepant results between two studies. Domest. Anim. Endocrinol., v.41, p.35-41, 2011.

WEETH, L.P.; FASCETTI, A.J.; KASS, P.H.; SUTER, S.E. Prevalence of obese dogs in a population of dogs with cancer. Am. J. Vet. Res., v.68, p.389-398, 2007. 